\title{
GENAI SVARBŪS STOROSIOS ŽARNOS VĖŽIO PATOGENEŻंJE
}

\author{
DANGUOLE RAULINAITYTE், RASA UGENSKIENE், RASA JANČIAUSKIENE், \\ ELONA JUOZAITYTE், LAURA KAIREVIČE் \\ Lietuvos sveikatos mokslu universiteto Medicinos akademija, Onkologijos institutas
}

\begin{abstract}
Raktažodžiai: storosios žarnos vèžys, genai, molekuliniai mechanizmai.
\end{abstract}

\begin{abstract}
Santrauka
Storosios žarnos véžys vystosi kaupiantis genetiniams ir epigenetiniams pokyčiams, dèl kuriu normalios epitelio lastelès virsta invazine karcinoma. Kiekviename storosios žarnos naviko formavimosi etape dalyvauja skirtingi genai. Manoma, kad naviko iniciacijai svarbūs APC ir MMR genu pokyčiai, tolesnei progresijai - KRAS, BRAF, malignizacijos procesui - TP53, DCC ir kt. Normaliu lasteliu piktybejjimas vyksta dèl chromosominio ir mikrosatelitu nestabilumu bei CpG salu metilinimo. Šie genomo persitvarkymai salygoja onkogenu aktyvinima, navika slopinančiu genu inaktyvacija ir pokyčius DNR reparacijos genuose.
\end{abstract}

\section{IVADAS}

Storosios žarnos vėžys yra piktybinis navikas, augantis tiesiosios ir/ar gaubtinès žarnos sieneleje. Pagal sergamumą onkologinemis ligomis, ši vėžio forma pasaulyje užima trečią vietą, o Lietuvoje yra viena iš penkių dažniausiai pasitaikančių vėžio lokalizacijų. Apie 90 proc. šios ligos atvejų yra sporadiniai ir tik $\sim 10$ proc. paveldimi. Kol kas nėra tiksliai žinoma, kokios yra šios ligos priežastys, tačiau manoma, kad gyvenimo būdas ir genetiniai bei epigenetiniai veiksniai yra itin svarbūs storosios žarnos véžio formavimuisi.

Storosios žarnos vėžys vystosi kaupiantis genetiniams ir epigenetiniams pokyčiams, dèl kurių normalios epitelio ląstelès virsta invazine karcinoma. Tai daugiaetapis procesas, kuriame gali dalyvauti daugiau kaip 20 skirtingų genų, svarbiu WNT- $\beta$-katenino, TGF- $\beta$, EGFR-MAPK ir PI3K signalo perdavimo sistemose.

Straipsnyje apžvelgiami molekuliniai mechanizmai bei genai, svarbūs storosios žarnos navikų etiopatogenezèje.

\section{DARBO OBJEKTAS}

Molekuliniai mechanizmai, svarbūs storosios žarnos vèžio formavimuisi. Normalių ląstelių piktybèjimas gali vykti dèl keleto molekulinių mechanizmų: chromosominio nestabilumo (angl. chromosomal instability CIN), mikrosatelitų nestabilumo (angl. microsatellite instability MSI) ir CpG salų metilinimo (angl. CpG island methylator phenotype CIMP). Dažniausiai storosios žarnos navikuose nustatomas chromosomų nestabilumas ( $\sim 85$ proc.), kurị lemia laipsniškas mutacijų kaupimasis. Tuomet vyksta chromosomų struktūros persitvarkymai, heterozigotiškumo praradimas, translokacijos, amplifikacijos ir delecijos. Nepaisant didelio CIN dažnio, tikslūs mechanizmai, sukeliantys šio tipo genetinius pokyčius, nèra dar iki galo aiškūs.

Kitas genetinis mechanizmas - mikrosatelitų nestabilumas. Jis storosios žarnos navikuose sutinkamas $\sim 15$ proc. dažniu. Mikrosatelitai yra 20-200 bazių porų (bp) ilgio DNR sekos, sudarytos iš $1-5$ bp pasikartojimų. Jos sudaro apie 3 proc. viso genomo. Skirtingai nuo chromosominio nestabilumo, mikrosatelitų nestabilumo priežastys yra pakankamai aiškios. Dėl pažaidų DNR nesuporuotų nukleotidų reparacijos sistemoje (angl. mismatch repair $M M R$ ) kaupiasi replikacijos klaidos ir pasikartojančios sekos igauna ar praranda pasikartojančius vienetus - susiformuoja mikrosatelitų nestabilumas.

CpG salų metilinimas yra trečiasis, epigenetinis, mechanizmas svarbus formuojantis storosios žarnos vėžiui. Netipiškas, aberantinis šių salų metilinimas sukelia naviką slopinančių genų, DNR reparacijos ir ląstelès ciklą reguliuojančių genų transkripcinị ,,nebylumą“, tokiu būdu prisidèdamas prie storosios žarnos vėžio vystymosi.

Šie genomo persitvarkymai inicijuoja pokyčius protoonkogenuose, naviką slopinančiuose genuose ar DNR reparacijos genuose. Dèl mutacijų proonkogenuose, ịprastuose žmogaus genuose, susidaro neịprastai aktyvūs onkogenai. Jų produktai, onkobaltymai, sustiprina augimo ir dalijimosi signalų sklidimą ląsteleje, slopina mirties signalus ir taip skatina ląstelių piktybejjimą ir metastazavimą. Priešingai, naviką slopinantys genai stabdo ląstelès piktybejjimą. Jie kontroliuoja ląstelès dalijimosi, DNR reparacijos, apoptozès ir kitus svarbius procesus. Mutacijos inaktyvina naviką slopinančius genus ir sumažina jų koduojamų baltymų raišką bei aktyvumą. Daugybė specifinių mutacijų, ìvykusių minètuose genuose, suteikia navikinėms ląstelėms naujų 
savybių, tokių kaip sugebejjimas išvengti apoptozės, pasipriešinti antiproliferaciniams signalams, stimuliuoti angiogenezę ir galiausiai metastazuoti. Mutacijos DNR reparacijos genuose stipriai padidina mutacijų dažni ir sąlygoja mutacijų kaupimąsi onkogenuose ir naviką slopinančiuose genuose.

Genai svarbūs storosios žarnos vẻžio iniciacijai. $\boldsymbol{A P C}$. Storosios žarnos véžio formavimasis yra daugiaetapis procesas, prasidedantis nuo ankstyvos adenomos ir per keletą stadijų pereinantis į vèlyvą metastazinę karcinomą. Dažniausiai ( 80 proc. atvejų) navikai formuojasi iš gerybiniu polipų, rečiau - de novo, t.y. normalioje žarnos gleivinèje ( 20 proc. atvejų). Gerybinių polipų formavimąsi inicijuoja $A P C$ (angl. adenomatous polyposis coli) geno inaktyvacija, kuri sukelia Šeiminès adenominès polipozés sindromą $(\breve{S} A P)$. Nepašalinti polipai turi polinki piktybèti ir, kaupiantis kitų genų mutacijoms, progresuoti į storosios žarnos vėžį. $A P C$ geno mutacijos yra vieni dažniausių ( $~ 80$ proc.) genetinių pokyčių storosios žarnos vėžio genezejje (1).

$A P C$ yra navika slopinantis genas, esantis $5 \mathrm{q} 21$ lokuse ir koduoja $312 \mathrm{kDa}$ baltymą, kuris atlieka pastolinio baltymo funkciją. Jis veikia ląstelių adheziją, migraciją ir yra svarbus ląstelių ciklo kontrolei, nes inhibuoja ląsteliu judejjimą iš $\mathrm{G}_{0} / \mathrm{G}_{1}$ i $\mathrm{S}$ fazę. $A P C$ dalyvauja WNT signalo perdavimo kelyje, kuris reguliuoja $\beta$-katenino fosforilinimą ir degradaciją. Esant $A P C$ geno mutacijai, $\beta$-kateninas kaupiasi citoplazmoje ir rišasi prie Tcf transkripcijos faktorių, keisdamas kitų genų, ịtakojančių ląstelių proliferaciją, diferenciaciją, migraciją ir apoptozę, ekspresiją.

$A P C$ geno mutacijos laikomos ankstyviausiu įvykiu storosios žarnos vèžio patogenezeje. Šio geno mutacijų buvo rasta mažiausiose pirminèse adenomose ir jų dažnis išliko pastovus tolesniuose ląstelių piktybejjimo procesuose. Daugumoje atvejų nustatomi abiejų $A P C$ geno alelių pokyčiai: vieno alelio delecija, o kito mutacija, arba abieju alelių mutacijos. Dažniausiai sutinkamos rèmelio poslinkio (68 proc.), nonsense (beprasmès mutacijos) (30 proc.) tipo mutacijos, rečiau - stambios delecijos (2 proc.), kurios gali sukelti baltymo sutrumpèjimą $\mathrm{C}$-terminaliniame regione ar visišką baltymo inaktyvaciją. Mutacijos dažniausiai ivyksta 15-to egzono, 5'gale, kitaip dar vadiname mutaciju kaupimosi regione, kuriame dažniausiai mutuoja kodonai, esantys 1061 ir 1309 pozicijose. Nustatyta, kad net 80 proc. $A P C$ mutacijų ịvyksta būtent šiame mutacijų kaupimosi regione (2).

MMR. Storosios žarnos vèžio vystymasis normalioje žarnos gleivinèje yra susijęs su Lynčo sindromu arba kitaip paveldimu nepolipoziniu storosios žarnos véžiu (angl. Hereditary nonpolyposis colorectal cancer HNPCC). Ši sindromą inicijuoja DNR nesuporuotų nukleotidų reparacijos
(MMR) genų mutacijos, sukeliančios mikrosatelitų nestabilumą (MSI). Šių genų mutacijos yra susijusios su padidejjusia (70-80 proc.) storosios žarnos vėžio rizika. Lynčo sindromo atveju $A P C$ mutacijos gali ivvykti po $M M R$ genų mutacijų (3).

$M M R$ sistema palaiko genomini stabilumą, atpažindama ir pašalindama insercines ar delecines mutacijas, kurios ịvyksta per DNR replikaciją. Pilnai $M M R$ sistemai yra reikalingi mažiausiai šeši skirtingi baltymai: hMSH2, hMLH1, hPMS1, hPMS2, hMSH3, hMSH6. Ivykus DNR pažaidoms jie dalyvauja poreplikacinèje reparacijoje, o kuomet DNR pažaidų ištaisyti neįmanoma - apoptozėje. Šiuos baltymus koduojančių genų mutacijos dažniausiai ivyksta $h M S H 2$ (38 proc.) ir hMLH1 (49 proc.), rečiau MSH6 (10 proc.) ir PMS ( $<5$ proc.) genuose. Nustatyta, $\operatorname{kad} h M S H 2$ ir $h M L H 1$ genu mutacijos yra svarbios nepolipozinio storosios žarnos vėžio vystymosi pradžiai (4).

hMSH2 genas, esantis 2p21 lokuse, koduoja baltymą, kuris formuoja heterodimera su hMSH6 ar hMSH3 baltymais (priklausomai nuo pažaidos tipo) ir jungiasi prie pažaidos vietos. $h M S H 2$ ir hMSH6 kompleksas vadinamas hMutS $\alpha$; jis yra būtinas ištaisyti vienos bazès neatitikimą. $h M S H 2$ ir $h M S H 3$ kompleksas vadinamas hMutS $\beta$ ir yra reikalingas ištaisyti insercijos - delecijos kilpą. $h M L H 1$ genas, esantis 3p21-23 lokuse, koduoja baltymą, kuris kartu su hPMS2 baltymu jungiasi su hMutS $\alpha$ ir hMutS $\beta$ i neatitikimų atpažinimo kompleksą. Pastarasis vejliau kartu su kitais baltymais dalyvauja DNR iškirpimo, resintezès ir sujungimo procesuose (4).

$h M L H 1$ ir $h M S H 2$ genų inaktyvaciją gali sukelti mutacijos arba geno promotoriaus hipermetilinimas, kuris dažnai nustatomas sergantiems storosios žarnos věžiu. Išjungus $M M R$ genus, kaupiasi replikacijos klaidos ir susiformuoja trumpų pasikartojančių nukleotidų sekų, mikrosatelitų, nestabilumas. Mikrosatelitų aleliai igauna ar praranda pasikartojančius vienetus, dèl kurių pasikeičia jų ilgis. Su $M S I$ susiję $M M R$ genų pokyčiai nustatomi 20 proc. visų storosios žarnos vėžių, $15-20$ proc. sporadinių ir 85 proc. paveldimų navikų (5).

Genai, dalyvaujantys premalignizacijos procese. Nors $A P C$ genas yra iniciatorius storosios žarnos véžio patogenezejje, vien tik šio geno mutacijų nepakanka tolimesnei adenomos progresijai. Daugelis adenomų lieka mažos. $B R A F, K R A S$ ir PIK3CA genų mutacijos įvyksta ankstyvoje adenomos vystymosi fazeje ir, manoma, kad šie pokyčiai gali sudaryti sąlygas tolesniam adenomų augimui. Šių genų mutacijos laikomos sekančiais pirmais genetiniais ịvykiais storosios žarnos karcinogenezèje, dar prieš ląstelių malignizaciją.

KRAS. KRAS genas yra vienas iš RAS onkogenų šei- 
mos narių. Jis dalyvauja Ras/Raf/MEK/MAP kinazių kaskadoje, kuri svarbi viduląsteliniams signalo perdavimams nuo aktyvuotų ląstelès paviršiaus receptorių iki transkripcijos faktoriu ląstelès branduolyje. Visi RAS šeimos mutuoti onkogenai (KRAS, HRAS ir NRAS) gali transformuoti ląsteles, tačiau $K R A S$ geno mutacijos yra dažniausiai nustatomos sergantiems storosios žarnos vėžiu (6).

KRAS genas, esantis 12p12.1 lokuse, koduoja GTP (guanozin-5'-trifosfatas) rišančius baltymus. Jie dalyvauja perduodant signalus iš receptorinių tirozino kinazių, tokių kaip epidermio augimo faktoriaus receptorius (EGFR). $K R A S$ turi dvi konfiguracijas: aktyvią KRAS-GTP ir neaktyvią $K R A S$-GDP. $K R A S$-GTP/GDP balansą griežtai reguliuoja guanino nukleotido pasikeitimo faktoriai ir GPTazes aktyvuojantys baltymai. Bet koks KRAS-GTP/GDP balanso sutrikdymas skatina naviko vystymąsi (7).

KRAS geno mutacijos ivyksta ankstyvoje storosios žarnos tumurogenezès stadijoje. Ivykus KRAS mutacijai, panaikinamas GPTazès aktyvumas bei sukeliama nevaldoma ląstelių proliferacija ir piktybiniai pakitimai. Aktyvuojančios $K R A S$ mutacijos lemia nuo EGFR nepriklausomą RAS/MAPK signalo perdavimo kelio stimuliaciją, kuri sustiprina ląstelès augimą, proliferaciją ir išgyvenamumą. Mutuotas KRAS randamas 30-50 proc. storosios žarnos karcinomos atvejų. Didžioji dauguma aktyvuojančių KRAS geno mutacijų nustatoma antrame egzone: $\sim 80$ proc. - 12 kodone, $\sim 20$ proc. - 13 kodone. Mažiau kaip 10 proc. visų mutacijų randama trečiame (61 ir kiti kodonai) ir ketvirtame egzonuose (146 kodonas). Dažniausi mutacijų tipai sutinkami šiuose egzonuose yra $\mathrm{G} \rightarrow \mathrm{A}$ tranzicija ir $\mathrm{G} \rightarrow \mathrm{T}$ transversija (7).

BRAF. $B R A F$ yra kitas svarbus genas, dalyvaujantis vystantis karcinomai iš ankstyvos adenomos. Šio geno (7q34 lokusas) koduojamas baltymas priklauso RAF baltymų šeimai, kuri koduoja serino/treonino kinazes. Šios kinazès dalyvauja Ras/Raf/MEK/MAP signalo perdavimo sistemoje bei stimuliuoja signalo perdavimą per MEK/ MAPK.

BRAF yra svarbus ląstelių proliferacijai, diferenciacijai ir apoptozei. Mutavus $B R A F$, hiperaktyvinama signalu perdavimo sistema ir sukeliamas neribotas ląstelès augimas. Dažniausiai BRAF geno mutacijos ịvyksta 11 (468 kodonas) ir 15 egzonuose (596, 600 kodonai). Daugiau kaip 95 proc. visų $B R A F$ mutacijų sudaro 15 egzono V600E taškinè mutacija, kurios metu glutaminas pasikeičiamas valinu dèl ivvykusios $\mathrm{T}>\mathrm{A}$ transversijos (8).

$B R A F$ genų mutacijos (4-12 proc.) sutinkamos ankstyvose storosios žarnos vėžio stadijose. Nors $K R A S$ ir $B R A F$ yra to pačio signalinio kelio nariai, jų mutacijos yra nesuderinamos, t.y. mutuoja arba $K R A S$ arba $B R A F$. Mutacijos šiuose genuose vyksta dèl skirtingų mechanizmų. Skirtingai nuo KRAS, BRAF mutacijos susiję su CpG salų metilinimu ir mikrosatelitų nestabilumu. Nustatyta, kad $B R A F$ geno mutacijos yra daug dažnesnès ( $\sim 50$ proc.) navikuose su MSI, negu navikuose su stabiliais mikrosatelitais $(\sim 5$ proc.) (9). Šio geno mutacijų dažnis priklauso ir nuo storosios žarnos vėžio lokalizacijos. M Kalady ir kt. nerado $B R A F$ geno mutacijų tiesiosios žarnos karcinomose, bet nustatė mutavusi $B R A F$ (17 proc.) gaubtinès žarnos navikuose (10).

PIK3CA. Fosfatidilinozitolio 3-kinazès (PI3K) yra lipidinių kinazių šeima, kuri reguliuoja ląstelių proliferaciją, išgyvenamumą, adheziją, diferenciaciją, citoskeleto persitvarkymą bei intraląstelinį judejjimą. PI3K yra heterodimeras, sudarytas iš reguliacinio p85 ir katalizinių p110 subvienetų. Žinoma keletas katalizinio subvieneto izoformų, tarp kurių tik $\alpha$-tipo katalizini subvienetą koduojančiame PIK3CA gene buvo rastos mutacijos ir amplifikacijos, svarbios įvairių žmogaus navikų patogenezèje. Reguliacinis p85 subvienetas gali specifiškai surišti baltyminius faktorius ir aktyvuoti PIK3CA.

PIK3CA, esantis 3q26.3 lokuse, susideda iš 20 egzonų bei koduoja iš 1068 amino rūgščių susidedantị peptidą. PIK3CA veikia kaip onkogenas. Šis baltymas katalizuoja fosfatidilinozitolio-4,5-bifosfato (PIP2) fosforilinimą iki fosfatidilinozitolio-3,4,5-trifosfato (PIP3), kuris yra svarbus ląstelių augimui, proliferacijai ir išgyvenamumui. Mutavus PIK3CA, stimuliuojamas AKT fosforilinimas, lemiantis padidejjusią PI3K/AKT signalinio kelio aktyvaciją, ląstelių proliferaciją, invaziją ir neoangiogenezę (11).

Apie 10-30 proc. storosios žarnos navikų randamos PIK3CA geno mutacijos. 80 proc. visų šio geno mutacijų nustatoma helikaziniame (9 egzonas) ir kinaziniame (20 egzonas) domenuose, kurie yra mutacijų kaupimosi karštieji taškai (12). Žinoma PIK3CA geno amplifikacija. Jehan ir kt. nustate, kad PIK3CA geno amplifikacija yra dažna storosios žarnos navikuose ir yra susijusi su $p 110$ baltymo ekspresijos padidejimu. Šio geno amplifikacija buvo rasta ne tik karcinomoje, bet ir adenomoje, todèl laikoma svarbiu mechanizmu adenomos - karcinomos transformacijoje (13).

Genai, dalyvaujantys storosios žarnos vėžio progresijoje. Piktybinè transformacija - tai biologiškai sudètingas procesas, dažnai atsirandantis dèl aktyvuotų onkogenų ir inaktyvuotų naviką slopinančių genų. Sutrikdomas normalus balansas tarp ląstelių proliferacijos ir apoptozès. Adenomos virtimą karcinoma sąlygoja daug mutuotų genų, nuo kurių priklauso tolesnè kancerogenezès eiga ir sudètingumas. Manoma, kad TP53 genas yra kaip tarpine grandis. Šio geno mutacijos lemia ląstelių piktybėjimą (pvz., ade- 
nomos transformaciją ị karcinomą) (14). Tolesniuose malignizacijos procesuose nustatomi kitų svarbių genų ( $D C C$, $P T E N$ ir kt.) pokyčiai. Jie dalyvauja karcinomos formavimosi, invazijos ir metastazavimo procesuose.

TP53. TP53 yra naviką slopinantis genas, esantis 17 p13.1 lokuse. Šis genas koduoja p53 baltymą, kuris tiesiogiai rišasi su DNR ir veikia kaip transkripcijos faktorius. Aktyvuotas p53 sustabdo ląstelès ciklą pažaidų ištaisymui arba indukuoja ląstelès apoptozę, kai pažaidų ištaisymas neįmanomas. Mutuotas p53 gali prisidèti prie navikinių ląsteliu proliferacijos ir angiogenezès aktyvinimo bei navikinių ląstelių apoptozès ir hipoksijos sumažinimo (15).

TP53 mutacijos itin dažnos ịvairiose žmogaus vėžinèse ląstelèse. Tai vienas iš svarbių genetinių mechanizmų storosios žarnos karcinogenezeje. Daugelio autorių duomenimis, 40-60 proc. storosios žarnos navikų nustatomas mutavęs TP53, ypač vèlyvoje adenomos virsmo karcinoma stadijoje (16). Pokyčiai šiame gene rodo blogą prognozę, kuri priklauso nuo mutacijos lokalizacijos. Nustatyta, kad septinto egzono mutacijos labiausiai paplitę paskutinèse storosios žarnos vėžio stadijose ir lemia blogiausią prognozę, palyginus su mutacijomis kituose egzonuose (17).

Daugumoje navikų nustatoma vieno TP53 alelio delecija ir kito alelio mutacija. Apie 95 proc. TP53 geno mutacijų ivvyksta 5-8 egzonuose. Šis regionas svarbus tretinès baltymo struktūros stabilizavimui ir tiesioginiam rišimuisi prie DNR. Mutacijų spektras labai įvairus. Dažniausios ( $\sim 85$ proc.) yra missense (klaidingos prasmès mutacijos) $(175,245,248,273$ ir 282 kodonuose), retesnès - nonsense ir rèmelio poslinkio mutacijos (15).

DCC. Storosios žarnos karcinomai būdingas 18q chromosomos heterozigotiškumo praradimas (angl. loss of heterozygosity $\mathrm{LOH}$ ). Šis procesas nèra dažnas mažose adenomose, todèl manoma, kad 18q LOH labiau prisideda prie storosios žarnos véžio progresavimo, o ne prie ligos iniciacijos. Daugiau kaip 90 proc. ankstyvų storosios žarnos karcinomų turi alelių praradimo regioną, kuriame yra $D C C$ (angl. deleted in colon cancer) genas (18).

$D C C$ yra gana didelis naviką slopinantis genas, esantis $18 \mathrm{q} 21.2$ lokuse, sudarytas iš 57 egzonu ir $\sim 1,2$ milijono bazių porų. $D C C$ genas koduoja keletą skirtingų baltymų, kurie atsiranda dèl alternatyvaus splaisingo (sukirpimo). Visos šio baltymo izoformos yra transmembraniniai glikoproteinai, panašūs ị nervinèse ląstelèse randamą adhezijos molekulių šeimą (18). Šio geno koduojamas transmembraninis baltymas dalyvauja adhezijos procese, svarbus ląsteliu augimui ir diferenciacijai, indukuoja apoptozę, reguliuoja ląsteliu išgyvenamumą, tokiu būdu slopindamas piktybinès transformacijos iniciaciją. Inaktyvavus $D C C$, pastebèta mažesnè ląstelių tarpusavio sąveika, prasta dife- renciacija ir padidejusi ląstelių proliferacija (19).

Apie 50-70 proc. storosios žarnos navikų nustatoma $D C C$ geno ekspresijos sumažèjimas ar visiškas jos nebuvimas. Tai palyginti vėlyvas ịvykis storosios žarnos kancerogenezèje ir yra siejamas su ląstelių metastazavimu. Tipiškai naviką slopinančių genų inaktyvacija ịvyksta dèl vieno alelio praradimo $(\mathrm{LOH})$ ir kito alelio mutacijų. Dažniausiai $D C C$ ekspresijos sumažejimas nustatomas praradus vieno alelio funkciją, labai retai - abiejų (20). Storosios žarnos navikuose nustatyta keletas nonsense, missense mutaciju koduojančioje $D C C$ geno sekoje, taip pat mutacijų sukuriančių naujas akceptorines kirpimo sritis. $D C C$ genui būdinga ir insercinè mutagenezè.

TGFBR2. TGF- $\beta$ signalinis kelias svarbus reguliuojant proliferaciją, diferenciaciją, apoptozę, migraciją ir ląsteliu homeostazę. Jis gali veikti kaip ląstelių inhibicijos sistema, slopinanti ne tik normalių epitelinių, bet ir vėžinių ląsteliu dauginimąsi pradinèse neoplazijos stadijose. Storosios žarnos navikams būdinga TGF- $\beta$ signalinio kelio disreguliacija (21).

Signalo perdavimas prasideda TGF- $\beta$ ligandui prisijungus prie TGF- $\beta$ II tipo receptoriaus. Jis yra serino/treonino kinazè, katalizuojanti I tipo receptoriaus ir jo reguliuojamos R-SMAD (SMAD2/3) fosforilinimą. R-SMAD gali jungtis prie ko-SMAD (SMAD4). Susidarę R-SMAD/ko-SMAD kompleksai patenka i branduoli, kur veikia kaip transkripcijos faktoriai ir dalyvauja reguliuojant genų - taikinių raišką (22). TGF- $\beta$ signalinio kelio disreguliaciją lemia signalo perdavime dalyvaujančių receptorių mutacijos.

TGFBR2 yra naviką slopinantis genas, koduojantis TGF- $\beta$ II-tipo receptorių. Jis inhibuoja ląstelių proliferaciją. Šiam genui būdinga ilga mononukleotido adenino seka trečiame egzone ir GT mikrosatelitine seka penktame ir septintame egzonuose. Mikrosatelitų sekos yra linkusios i replikacijos klaidas, ypač esant $M M R$ genų inaktyvacijai. Esant mikrosatelitų nestabilumui, daugiau kaip 90 proc. $T G F B R 2$ geno mutacijų ivvyksta šiame regione. Mutacijos sukelia geno inaktyvaciją ir yra būdingos storosios žarnos navikams ( $\sim 30$ proc.). Dažniausiai nustatomos rèmelio poslinkio ( $\sim 80$ proc.), rečiau ( $\sim 15$ proc.) - missens mutacijos, ypač vèlyvose adenomos stadijose. TGFBR1 geno, koduojančio TGF- $\beta$ I-tipo receptorių, mutacijos nèra dažnai sutinkamos storosios žarnos navikuose. B Pasche ir kt. nustatè, kad TGFBR1 geno mutacijos skatina ląstelių proliferaciją ir prisideda prie storosios žarnos vėžio išsivystymo (23).

SMAD2/3/4. TGF- $\beta$ signalinio kelio inaktyvaciją gali sukelti SMAD2/3/4 baltymus koduojančiu genu delecijos ir mutacijos. SMAD4 genas (18q21.1 lokusas) koduoja baltymą, kuris veikia ir kaip transkripcijos faktorius, kontroliuodamas tam tikrų genų veiklą ir kaip naviką slopinantis 
genas, inhibuodamas nevaldomą ląstelių augimą. 10-25 proc. storosios žarnos navikų nustatoma šio geno delecija ar ekspresijos inaktyvacija. SMAD4 gene randamos remelio poslinkio, nonsense ir missense mutacijos, kurios daugiau kaip 80 proc. ivyksta $\mathrm{MH} 2$ regione, kurio 361 kodonas yra missense mutacijų karštasis taškas. SMAD4 geno mutacijos siejamos su Jaunatviniu polipoziniu sindromu, kuriam būdingas hamartominiu polipu ir storosios žarnos vėžio išsivystymas. Tiriant visas storosios žarnos vėžio stadijas nustatyta, kad SMAD4 geno inaktyvacija yra vẻlyvas įvykis storosios žarnos karcenogenezèje (22). Panašius tyrimus atlikęs S Biswas ir kt. patvirtino, kad SMAD4 geno funkcijos praradimas įvyksta vèlesnèse navikų piktybejjimo stadijose. Šio geno mutacijų dažnis dideja progresuojant kancerogenezei; daugiausia šio geno mutacijų buvo surasta invazinèse ir metastazinèse karcinomose (24).

SMAD2 veikia kaip naviką slopinantis genas ir yra visai šalia SMAD4 geno, 18q chromosomoje. Šio geno koduojamas baltymas dalyvauja TGF- $\beta$ signalo perdavimo kelyje ir prisideda prie ląstelių proliferacijos, diferenciacijos ir apoptozès reguliavimo. Mutuotas SMAD2 sutrikdo normalų signalo perdavimą tarp ląstelès membranos receptorių ir branduolio ir sudaro galimybę ląstelèms išvengti TGF- $\beta$ antiproliferacinio efekto. Šio geno mutacijos sutinkamos $\sim 6$ proc. dažnumu ir būdingos ankstyvoms storosios žarnos vėžio stadijoms (23).

SMAD3 genas, esantis 15q22.33 lokuse, koduoja baltymą, kuris kaip ir kiti SMAD šeimos baltymai dalyvauja TGF- $\beta$ signalo perdavime. Šio geno mutacijos labai retai nustatomos žmogaus storosios žarnos navikuose, tačiau pelëms igimta homozigotinė SMAD3 mutacija sąlygojo storosios žarnos adenokarcinomos išsivystymą. Manoma, kad šio geno mutacijos nèra svarbios storosios žarnos karcinogenezeje (23).

PTEN. PTEN (fosfato ir tenzino homologas) yra svarbus navika slopinantis genas, esantis 10q23.3 lokuse. Jis koduoja $47 \mathrm{kDa}$ specifinę lipidų ir baltymų fosfatazę PTEN, kurios pagrindinis substratas yra antrinis signalo perdavèjas PIP3. PTEN veikia priešingai nei $P I 3 K$ t.y. defosforilina $\mathrm{PIP}_{3}$ i $\mathrm{PIP}_{2}$ ir inhibuoja AKT signalini kelią. PTEN taip pat gali defosforilinti pagrindinę adhezijos kinazę (FAK) bei slopinti shc fosforilinimą taip blokuodamas RAS/MAP signalinio kelio aktyvumą. PTEN dalyvauja ląstelių adhezijos, plitimo ir atpažinimo procesuose. Sutrikus PTEN funkcijai, padidejja PIP3 koncentracija, hiperaktyvuojamas AKT. Šis baltymas kontroliuoja ląsteliu proliferaciją ir apsaugo ląsteles nuo apoptozès, todèl, įvykus AKT hiperaktyvacijai, ląstelès išvengia apoptozinių signalų (25).

PTEN inaktyvuojamas dèl alelio heterozigotiškumo praradimo, geno mutacijų, delecijų ar promotoriaus hiper- metilinimo. Dažniausios šio geno mutacijos, insercijos ir delecijos nustatomos septintame ir aštuntame egzonuose, adenino bazių poli(A) uodegoje (26). Storosios žarnos navikuose PTEN geno inaktyvacija susijusi su mikrosatelitų nestabilumu (MSI). Nustačius MSI, šio geno pokyčių sutinkama iki 30 proc., o stabilių mikrosatelitų atveju $\sim 9$ proc. (27).

Manoma, kad PTEN dalyvauja storosios žarnos karcinomos progresijoje, nes šio baltymo ekspresija laipsniškai mažeja normalaus epitelio-adenomos-adenokarcinomosmetastatinès adenokarcinomos sekoje. Tikètina, kad PTEN prisideda prie karcinomos augimo, invazijos ir metastazavimo (28). Paveldimos PTEN geno mutacijos sukelia Cowdeno sindromą, kurio metu visame kūne formuojasi daugybinès hamartomos, kurios gali padidinti storosios žarnos vėžio tikimybę $\sim 10$ proc. (29). Rustgi ir bendraautoriai mano, kad Cowdeno sindromas nedidina storosios žarnos vėžio rizikos (30).

FBXW7. $F B X W 7$ (arba kitaip $C D C 4$ ) yra naviką slopinantis genas (4q31.3 lokusas) ir koduojantis FBXW7 (F-dèžutè/WD pasikartojimą turintis baltymas 7) baltymą. FBXW7 yra ubikvitino ligazès komponentas. Jis reguliuoja kelių onkobaltymų (pvz. ciklino E, c-Myc, c-Jun ir Notch) degradaciją. Šie baltymai kontroliuoja ląstelès dalijimąsi, vystymąsi ir diferenciaciją.

FBXW7 geno inaktyvacija gali ịvykti dèl bialelinès mutagenezès ar vieno alelio mutacijos, o kito LOH (31). $F B X W 7$ mutacijos WD ir F-děžutės domenuose trukdo ciklino E jungimąsi ir inhibuoja šio baltymo proteolizę. Nustatyta, kad $F B X W 7$ funkcijos praradimas ir padidejusi ciklino $E$ ekspresija aktyvina nuo ciklinu priklausančia kinaze 2 (CDK2) ir sukelia CDKN1B baltymo, kuris veikia kaip ląstelès ciklo inhibitorius, pašalinimą iš ląstelès (32).

Storosios žarnos navikuose $F B X W 7$ geno mutacijos sutinkamos 6-8 proc. dažnumu. Vieni dažniausių pakitimų yra missens mutacijos WD domenuose, kurios mažina substrato sujungimą, rečiau nustatomas FBXW7 baltymo sutrumpejimas $\mathrm{NH}_{2}$ - terminalinio galo WD pasikartojimuose (31). 69 proc. visų šio geno mutacijų îvyksta trečiame, ketvirtame ir penktame WD pasikartojančiuose domenuose, kurie tarpininkauja atpažįstant substratus, o apie 19 proc. - F-dèžutèje, kuri dalyvauja substrato ir ubikvitino sujungime (33). Iwatsuki ir kt. nustatè, kad $F B X W 7$ genetiniu pakitimų dažnis didejja progresuojant ligai (34). Storosios žarnos adenomoje nustatoma apie 4-6 proc., o karcinomoje apie 7-12 proc. $F B X W 7$ geno mutaciju (35).

Epigenetiniai pokyčiai, svarbūs storosios žarnos vèžio formavimuisi. Epigenetiniai veiksniai yra neatsiejama genomo dalis, valdanti daugelị ląsteliniu procesų, tarp jų ir ląstelès piktybejimą. Epigenetinès pažaidos - tai paveldimi pokyčiai ląstelès genetinejje medžiagoje (DNR ir chroma- 
tine), dèl kurių sutrinka genų raiškos reguliacija. Skirtingai nuo genetinių, epigenetinès pažaidos nesukelia DNR nukleotidų sekos pokyčiu (mutacijų, delecijų ir kt.) ir yra grịžtamos, eliminavus toksinị veiksnị. Viena pagrindiniu epigenetinių pažaidų yra pakitęs DNR metilinimas.

DNR metilinimas - tai procesas, kurio metu, katalizuojant fermentui metiltransferazei, metilo grupe (-CH3) kovalentiškai prijungiama prie citozino anglies molekulès 5 pozicijoje ir susidaro metilintas citozinas (metilcitozinas). Dažniausiai citozinas metilinamas citozino ir guanino $(\mathrm{CpG})$ dinukleotiduose, citozinui esant prieš guaniną. Žinduolių ir žmonių ląstelèse metilinama apie $70-80$ proc. $\mathrm{CpG}$ citozinų. DNR regionai turintys didesnę $\mathrm{CpG}$ koncentraciją, vadinami $\mathrm{CpG}$ salomis. CpG salos - tai DNR sritys, kuriose daugiau kaip 55 proc. visų bazių sudaro citozinas ir guaninas. Normaliose ląstelèse $\mathrm{CpG}$ salos nemetilinamos, išskyrus moteru $\mathrm{X}$ chromosomų inaktyvinimo ir genomo imprintingo atvejus. $\mathrm{CpG}$ salos dažnai siejamos su genų reguliacinemis sritimis - promotoriais ir/ar pirmu egzonu. Šias salas turi apie 60 proc. žmogaus genų, kurie dalyvauja svarbiuose ląstelès procesuose (36).

Epigenetiniai pokyčiai yra svarbūs storosios žarnos vèžio patogenezèje. Pakitęs DNR metilinimas dažnai nustatomas tiriant storosios žarnos navikus. Vèžinèms ląstelèms būdingi trys su metilinimu susiję procesai: genomo hipometilinimas (angl. genome-wide hypomethylation), DNR metiltransferazių aktyvumo padidejjimas ir genų promotorinių sekų, CpG salų, metilinimas (angl. hypermethylation, aberrant methylation).

Genomo hipometilinimas - tai bendro metilcitozino kiekio sumažèjimas genome. Nors tikslūs mechanizmai nèra aiškūs, manoma, kad genomo hipometilinimą sąlygoja metiltransferazę koduojančio DNMT1 geno homozigotinès delecijos. Metilcitozino kiekio sumažejjimas genome daugiausia nustatomas $\mathrm{CpG}$ dinukleotiduose, esančiuose pasikartojančiose DNR sekose, tokiose kaip LINE-1 ar satelitiniai pasikartojimai (37). DNR hipometilinimas gali sukelti kelių onkogenų aktyvaciją (S100A4, c-myc, ciklinas D240 ir kt.), imprintingo (angl. imprint - žymè, atspaudas) praradimą (angl. loss of imprinting LOI), taip pat gali būti genominio nestabilumo priežastimi. Tyrimai su Dnmt1 $^{+/}$ pelèmis parodè, kad genomo hipometilinimas (per genomini nestabilumą) gali prisidèti prie navikų formavimosi. Nustatyta, kad imprintingo praradimas gali padidinti Igf2 ekspresiją ir predisponuoti onkologines ligas (38). Genominio metilcitozino kiekio sumažejimas yra būdingas adenominiams polipams ir yra apibūdinamas kaip ankstyvas ivvykis storosios žarnos navikogenezeje (39).

Padidejjusi DNR metiltransferazių ekspresija būdinga daugumai onkologinių ligų, tarp jų ir storosios žarnos navi- kams. Tyrimuose su gyvūnais ir ląstelių kultūromis nustatyta, kad padidejusi DNMT1 ir DNMT3b fermentų ekspresija indukuoja aberantinị $\mathrm{CpG}$ salų metilinimą. Metiltransferazių aktyvumo padidejimas vertinamas kaip ankstyvas ivykis storosios žarnos kancerogenezèje. Nustatyta, kad navikui progresuojant metiltransferazių kiekis dideja (40).

$\mathrm{CpG}$ salų metilinimas yra dažnas įvykis storosios žarnos karcinogenezeje. Manoma, kad šis epigenetinis pokytis inaktyvuoja daugiau genų, negu genetinès mutacijos. Aberantinis $\mathrm{CpG}$ salų metilinimas sukelia naviką slopinančiu genų (VHL, CDKN2A, CDKN2B ir kt.), DNR reparacijos ir ląstelès ciklą reguliuojančių genų transkripcijos represiją. Jis gali būti kaip alternatyvus mechanizmas (mutacijoms) šių genų inaktyvacijai. CpG metilinimas gali sutrikdyti svarbius signalo perdavimo kelius, dalyvaujančius visose vėžio stadijose: iniciacijoje, progresijoje, invazijoje ir metastazavime. Pavyzdžiui, DNR reparacijos genų, tokių kaip hMLH1, MGMT ar HICl CpG salu metilinimas gali inicijuoti navikogenezę, sukeldamas mikrosatelitų nestabilumą bei kitų svarbių genų, tokių kaip TP53 ir KRAS, mutacijas. $C D K N 2 A$ ir $C D H 1$ genu epigenetinis nutildymas siejamas su ląstelès ciklo kontrolès praradimu bei pokyčiais ląsteliu migracijos ir invazijos procesuose (40).

Normaliose ląstelèse $\mathrm{CpG}$ salos nemetilinamos. Nuo metilinimo jas saugo apsauginis barjeras, t.y. specifinès DNR sekos ir prie jų prisijungiantys baltymai, kurie neleidžia metilinimui plisti ị geno promotoriaus sritis (41). Apsauginio barjero molekuliniai mechanizmai nèra tiksliai žinomi. Manoma, kad vėžinèse ląstelèse šis barjeras gali būti suardomas dẻl baltymų ir transkripcijos veiksnių pokyčių bei metiltranferazès aktyvumo padidèjimo. Aberantinio CpG salų metilinimo metu, MBD (Methyl-CpG-binding domain) baltymas, atpažistantis metilintas DNR sekas, prisitvirtina prie metilintos $\mathrm{CpG}$ salos vietos. Jis pritraukia kitus baltymus, tokius kaip histonų deacetilazès. Šis baltymų kompleksas pertvarko chromatiną ị uždarą konformaciją, kuri pašalina transkripcijos faktorius iš promotorių srities ir sukelia genų transkripcijos nutildymą (42).

\section{APIBENDRINIMAS}

Storosios žarnos vėžio formavimasis yra daugiaetapis procesas, sąlygojamas genetinių ir epigenetinių pokyčių. Manoma, kad vieni svarbiausių molekulinių mechanizmų, dalyvaujančių šiame procese, yra chromosominis ir mikrosatelitų nestabilumai bei aberantinis $\mathrm{CpG}$ salų metilinimas. Dèl šių pokyčių ląstelejje aktyvinami onkogenai, sukeliama navika slopinančiu genu inaktyvacija bei pažaidos DNR reparacijos genuose. Tai keičia svarbius ląstelinius procesus, tokius kaip proliferacija, migracija, diferenciacija, adhezija, apoptoze, DNR stabilumas ir reparacija. Kiekvie- 
name storosios žarnos vèžio formavimosi etape dalyvauja skirtingi genai: iniciacijai svarbūs $A P C, M M R$, tolesniam vystymuisi - KRAS, $B R A F$, malignizacijos procesui - TP53, $D C C$ ir kt. genai. Manoma, kad daugiau kaip 20 skirtingu genų gali dalyvauti storosios žarnos tumorogenezejje. Tikètina, kad storosios žarnos karcinogenezès procese svarbiau ne konkrečių pavienių genų mutacijos, bet signalinių kelių, tokių kaip WNT- $\beta$-katenino, TGF- $\beta, E G F R$-MAPK ir PI3K, disreguliacija.

Storosios žarnos etiopatogenezèje svarbių genetinių ir epigenetinių mechanizmų išsamūs tyrimai leidžia geriau suprasti storosios žarnos vėžio atsiradimo priežastis. Nustačius genų, svarbių ligos iniciacijai ir progresijai, mutacijas galima prognozuoti ligos eigą, sunkumą, atsaką ì gydymą. Onkologinès ligos ịvertinimas molekuliniame lygyje yra svarbus žingsnis personalizuotos medicinos terapijos link.

\section{Literatūra}

1. Yang V. APC as a checkpoint gene: the beginning or the end? Gastroenterology. 2002;123(3):935-9.

2. Galiatsatos P, Foulkes WD. Familial Adenomatous Polyposis. Am J Gastroenterol. 2006;101:385-398.

3. Huang J, Zheng S, Jin S, Zhang S. Somatic mutations of APC gene in carcinomas from hereditary non-polyposis colorectal cancer patients. World J Gastroenterol. 2004;10(6):834-836.

4. Boland CR, Goel A. Microsatellite instability in colorectal cancer. Gastroenterology. 2010;138(6):2073-2087.

5. De Jesus-Monge WE, Gonzalez-Keelan C, Zhao R, Hamilton S, Rodriguez-Bigas M, Cruz-Correa M. Mismatch repair protein expression and colorectal cancer in Hispanics from Puerto Rico. Fam Cancer. 2010;9(2):155-166.

6. Jimeno A, Messersmith WA, Hirsch FR, Franklin WA, Eckhardt SG. KRAS mutations and sensitivity to epidermal growth factor receptor inhibitors in colorectal cancer: practical application of patient selection. J Clin Oncol. 2009;27(7):1130-6.

7. Liu X, Jakubowski M, Hunt JL. KRAS gene mutation in colorectal cancer is correlated with increased proliferation and spontaneous apoptosis. Am J Clin Pathol. 2011;135(2):245-52.

8. Phillips B, Kalady M, Kim R. BRAF testing in advanced colorectal cancer: is it ready for prime time? Clin Adv Hematol Oncol. 2010;8(6):437-44.

9. Lubomierski N, Plotz G, Wormek M, Engels K, Kriener S, Trojan J, Jungling B, Zeuzem S, Raedle J. BRAF mutations in colorectal carcinoma suggest two entities of microsatellite unstable tumors. Cancer. 2005;104(5):952-61.

10. Kalady M, Sanchez J, Manilich E, Hammel J, Casey G, Church J. Divergent oncogenic changes influence survival differences between colon and rectal adenocarcinomas. Dis Colon Rectum. 2009;52:1039-1045.

11. Manning BD, Cantley LC. AKT/PKB signaling: Navigating downstream. Cell. 2007;129(7):1261-74.

12. Zhao L, Vogt PK. Class I PI3K in oncogenic cellular transformation. Oncogene. 2008;27(41):5486-96.

13. Jehan Z, Bavi P, Sultana M, Abubaker J, Bu R, Hussain A, Alsbeih G, Al-Sanea N, Abduljabbar A, Ashari LH, Alhomoud S, Al-Dayel F, Uddin S, Al-Kuraya KS. Frequent PIK3CA gene amplification and its clinical significance in colorectal cancer. J Pathol. 2009;219:337-346.

14. Ghavam-Nasiri MR, Rezaei E, Ghafarzadegan K, Seilanian-Toosi M, Malekifard H. Expression of p53 in colorectal carcinoma: corre- lation with clinicopathologic features. Arch Iran Med. 2007;10(1):38-42.

15. Fearon ER. Molecular Genetics of Colorectal Cancer. Annu Rev Pathol Mech Dis. 2011;6:479-507.

16. Akkiprik M, Ataizi-Celikel C, Düşünceli F, Sönmez O, Gulluoglu BM, Sav A, Ozer A. Clinical significance of p53, K-ras and DCC gene alterations in the stage I-II colorectal cancers. J Gastrointestin Liver Dis. 2007;16(1):11-7.

17. Iacopetta B. TP53 mutation in colorectal cancer. Hum Mutat. 2003;21(3):271-6.

18. Zauber P, Solitare M, Marotta SP, Bishop T. Loss of Heterozygosity for Chromosome 18q and Microsatellite Instability. J Appl Res. 2008;8(1).

19. Mehlen P, Fearon ER. Role of the dependence receptor DCC in colorectal cancer pathogenesis. J Clin Oncol. 2004;22(16):3420-8.

20. Nighat P. Khan, Arshad A. Pandith, Mahboob U. 1. Hussain, Adfar Yousuf. Loss of heterozygosity (LOH) of deleted in colorectal cancer (DCC) gene and predisposition to colorectal cancer: Significant association in colorectal cancer patients of Kashmir. Journal of Cancer Research and Experimental Oncology. 2011;3(8):88-94.

21. Handra-Luca A, Olschwang S, Fléjou JF. SMAD4 protein expression and cell proliferation in colorectal adenocarcinomas. Virchows Arch. 2011;459(5):511-9.

22. Miyaki M, Kuroki T. Role of Smad4 (DPC4) inactivation in human cancer. Biochem Biophys Res Commun. 2003;306(4):799-804.

23. Xu Y, Pasche B. TGF-beta signaling alterations and susceptibility to colorectal cancer. Hum Mol Genet. 2007;16(1):14-20.

24. Biswas S, Trobridge P, Romero-Gallo J, Billheimer D, Myeroff LL, Willson JK, Markowitz SD, Grady WM. Mutational inactivation of TGFBR2 in microsatellite unstable colon cancer arises from the cooperation of genomic instability and the clonal outgrowth of transforming growth factor beta resistant cells. Genes Chromosomes Cancer. 2008;47(2):95-106.

25. Nassif NT, Lobo GP, Wu X, Henderson CJ, Morrison CD, Eng C, Jalaludin B, Segelov E. PTEN mutations are common in sporadic microsatellite stable colorectal cancer. Oncogene. 2004;23(2):617-28.

26. Goel A, Arnold CN, Niedzwiecki D, Carethers JM, Dowell JM, Wasserman L, Compton C, Mayer RJ, Bertagnolli MM, Boland $\mathrm{CR}$. Frequent inactivation of PTEN by promoter hypermethylation in microsatellite instability-high sporadic colorectal cancers. Cancer Res. 2004;64:3014-21.

27. Danielsen SA, Lind GE, Bjørnslett M, Meling GI, Rognum TO, Heim S, Lothe RA. Novel mutations of the suppressor gene PTEN in colorectal carcinomas stratified by microsatellite instability- and TP53 mutation-status. Hum Mutat. 2008;29:252-62.

28. Jang KS, Song YS, Jang SH, Min KW, Na W, Jang SM, Jun YJ, Lee KH, Choi D, Paik SS. Clinicopathological significance of nuclear PTEN expression in colorectal adenocarcinoma. Histopathology. 2010:56(2):229-239

29. Kersseboom R, Dubbink H, Corver W, van Tilburg A, Poley J, van Leerdam M, Atmodimedjo P, van de Laar I, Collée J, Dinjens W, Morreau H, Wagner A. PTEN in colorectal cancer: a report on two Cowden syndrome patients. Clin Genet. 2012;81(6):555-562.

30. Rustgi AK. The genetics of hereditary colon cancer. Genes Dev. 2007;21:2525-38

31. Kemp Z, Rowan A, Chambers W, Wortham N, Halford S, Sieber O, Mortensen N, von Herbay A, Gunther T, Ilyas M, Tomlinson I. CDC4 mutations occur in a subset of colorectal cancers but are not predicted to cause loss of function and are not associated with chromosomal instability. Cancer Res. 2005;65:11361-6.

32. Miyaki M, Yamaguchi T, Iijima T, Takahashi K, Matsumoto H, Mori T. Somatic Mutations of the CDC4 (FBXW7) Gene in Hereditary Colorectal Tumors. Oncology. 2009;76:430-434. 
33. Rajagopalan H, Jallepalli PV, Rago C, Velculescu VE, Kinzler $\mathrm{KW}$, Vogelstein B, Lengauer C. Inactivation of hCDC4 can cause chromosomal instability. Nature. 2004;428(6978):77-81.

34. Iwatsuki M, Mimori K, Ishii H, Yokobori T, Takatsuno Y, Sato T, Toh H, Onoyama I, Nakayama KI, Baba H, Mori M. Loss of FBXW7, a cell cycle regulating gene, in colorectal cancer: clinical significance. Int J Cancer. 2010;126(8):1828-37.

35. Welcker M, Singer J, Loeb KR, Grim J, Bloecher A, Gurien-West M, Clurman BE, Roberts JM. Multisite phosphorylation by Cdk2 and GSK3 controls cyclin E degradation. Mol Cell. 2003;12:381-92.

36. Lao VV, Grady WM. Epigenetics and colorectal cancer. Nat Rev Gastroenterol Hepatol. 2011;8(12):686-700.

37. Feinberg, A.P. The epigenetics of cancer etiology. Semin Cancer Biol. 2004;14:427-432.

38. Cui H, Onyango P, Brandenburg S, Wu Y, Hsieh CL, Feinberg AP. Loss of imprinting in colorectal cancer linked to hypomethylation of H19 and IGF2. Cancer Res. 2002;62:6442-6.

39. Fearon E.R. Molecular Genetics of Colorectal Cancer. Annu. Rev. Pathol. Mech. Dis. 2011;6:479-507.

40. Issa JP. The epigenetics of colorectal cancer. Ann N Y Acad Sci. 2000;910:140-53.

41. Caiafa, P, Zampieri M. DNA methylation and chromatin structure: the puzzling CpG islands. J. Cell Biochem. 2005;94:257-265.

42. Grady WM, Carethers JM. Genomic and epigenetic instability in colorectal cancer pathogenesis. Gastroenterology. 2008;135(4):1079-99.
GENES IMPORTANT IN THE PATHOGENESIS OF COLORECTAL CANCER

Danguole Raulinaitytè, Rasa Ugenskienè, Rasa Jančiauskienè, Elona Juozaitytè, Laura Kairevičé

Summary

Key words: Colorectal cancer, genes, molecular mechanisms.

Colorectal cancer results from the intracellular accumulation of both genetic and epigenetic changes that transform normal glandular epithelium into invasive adenocarcinoma. Each stage of colorectal tumor formation involves different genes. It is believed that changes of MMR and APC genes are important for the initiation, KRAS and BRAF - for further development of the tumor, Tp53, DCC and other genes are important for the malignization process. Normal cells can turn malignant due to chromosomal instability, microsatellite instability and methylation of $\mathrm{CpG}$ islands. These genome alterations usually determine the activation of oncogenes, inactivation of tumor suppressor genes or changes in DNA repair genes.

Correspondence to: danguoleraulinaityte@gmail.com

Gauta 2012-06-14 